\title{
1 Uncertainty in population estimates: a meta-analysis for petrels
}

\section{Authors}

3 Jeremy P. Bird ${ }^{1,2}$, Bradley K. Woodworth ${ }^{1}$, Richard A. Fuller ${ }^{1}$, Justine D. S. Shaw ${ }^{1}$

4 1. School of Biological Sciences, University of Queensland, Brisbane, QLD 4072, Australia

5 2. Institute of Marine and Antarctic Studies, University of Tasmania, 20 Castray Esplanade, Battery

$6 \quad$ Point, TAS 7004, Australia

7

8 Corresponding author

9 Jeremy P. Bird - jez.bird@uq.edu.au

Author contributions

$13 \mathrm{JB}$ conceived the ideas and completed the literature review; all authors contributed to methods; JB

14 and BW undertook the analysis; JB led the writing of the manuscript. All authors contributed

15 critically to the drafts and gave final approval for publication. 
17 1. Population estimates are commonly generated and used in conservation science. All estimates carry inherent uncertainty, but little attention has been given to when and how this uncertainty limits their use. This requires an understanding of the specific purposes for which population estimates are intended, an assessment of the level of uncertainty each purpose can tolerate, and information on current uncertainty.

2. We conducted a review and meta-analysis for a widespread group of seabirds, the petrels, to better understand how and why population estimates are being used. Globally petrels are highly threatened, and aspects of their ecology make them difficult to survey, introducing high levels of uncertainty into population estimates.

3. We found that by far the most common intended use of population estimates was to inform status and trend assessments, while less common uses were trialling methods to improve estimates, and assessing threat impacts and conservation outcomes.

4. The mean coefficient of variation for published estimates was 0.17 ( $S D=0.14)$, with no evidence that uncertainty has been reduced through time. As a consequence of this high uncertainty, when we simulated declines equivalent to thresholds commonly used to trigger management, only $5 \%$ of studies could detect significant differences between population estimates collected 10 years apart for populations declining at a rate of $30 \%$ over three generations.

5. Reporting of uncertainty was variable with no dispersion statistics reported with $38 \%$ of population estimates and most not reporting key underlying parameters: nest numbers/density and nest occupancy. We also found no correlation between population estimates and either island size, body size or species threat status - potential predictors of uncertainty.

6. Synthesis and applications-Key recommendations for managers are to be mindful of uncertainty in past population estimates if aiming to collect contemporary estimates for comparison, to report uncertainty clearly for new estimates, and to give careful consideration to whether a proposed estimate is likely to achieve the requisite level of certainty for the investment in its 
bioRxiv preprint doi: https://doi.org/10.1101/2021.04.07.438872; this version posted April 9, 2021. The copyright holder for this preprint (which was not certified by peer review) is the author/funder, who has granted bioRxiv a license to display the preprint in perpetuity. It is made available under aCC-BY-NC-ND 4.0 International license.

42 generation to be warranted. We recommend a practitioner-based Value of Information assessment

43 to confirm where there is value in reducing uncertainty.

44

45 KEYWORDS

46 Biodiversity conservation, Burrow-nesting, Population size, Population trend, Power analysis,

47 Procellariidae, Seabird, Wildlife monitoring 


\section{INTRODUCTION}

49

50

51

Population estimates are a foundation of conservation science, variously used to characterise the changing status of populations, manage harvests, assess threats to biodiversity, choose between and evaluate outcomes of conservation actions, and to communicate conservation messages (Jones et al., 2016; Nichols et al., 2007; Pressey et al., 2007; Rodrigues et al., 2006). Inherent in all population estimates is a level of uncertainty. Logically, the lower the uncertainty, the easier it is for managers to use an estimate to make an informed decision, but not all uncertainties are important to resolve (Runge et al., 2011). Uncertainty in a population estimate matters only where a course of action might change if that uncertainty is reduced. Given the trade-off between spending money on surveying biodiversity and spending it on management there is value in understanding the return on investment from estimating population sizes, and the benefit of reducing uncertainty of those estimates (Possingham et al., 2012; Runge et al., 2011).

Many biodiversity censusing and monitoring studies do not clearly state the purpose for their monitoring (Possingham et al., 2012). While conservation interventions may report their proximal goals, many fail to outline their ultimate objectives (Bird et al., 2019; Mackenzie \& Royle, 2005). For example, the proximal goal of poison-baiting an island may be to eradicate an invasive predator, but its ultimate goal of precipitating an increase in the population of a threatened species is not always stated or given a quantitative target. In such cases it is not possible to determine whether reducing uncertainty around a population estimate is worthwhile. If there is no direct mention of an outcome that will be informed by a population estimate, it begs the question is there any need to make that estimate? In cases where the purpose for generating a population estimate is clearly articulated, the cost of the estimate can be weighed against the benefit of reducing uncertainty around it (Canessa et al., 2015). While population estimates are widely reported and advocated, and are presumably attracting significant conservation resources, there has been little analysis of why population 
estimates are being generated, how much uncertainty they carry, and whether uncertainty in those estimates might hinder use for their stated management purpose.

Here we investigate uncertainty in population estimates for an entire taxonomic group of seabirds, the petrels (families Procellariidae, Hydrobatidae and Oceanitidae). Many studies have flagged uncertainty in population estimates as an issue, highlighting potential weaknesses of individual survey methods, and challenges in particular study systems (e.g. Arneill et al., 2019; Hatch, 2003; Sutherland and Dann, 2012). While these case studies hint at a potentially widespread issue, by reviewing the entire group we can assess trends in measurement and reporting of uncertainty and provide guidance on how it might best be tackled.

Understanding the size and trends of petrel populations is important ecologically and commercially because of the ecological function petrels play interacting with island-ocean food webs, fisheries and as a harvestable resource (Danckwerts et al., 2014; Graham et al., 2018; Newman et al., 2009; Otero et al., 2018). It is also important for conservation as 52 of 124 species (42\%) are threatened with extinction (Rodríguez et al., 2019). Petrels nest almost exclusively on remote islands where monitoring is rare (Warham, 1996). Transport is a major component of costs, so infrequent but large-scale surveys tend to be more prevalent than frequent small-scale monitoring visits (Buxton et al., 2016; Rodríguez et al., 2019). As a result, changes are often inferred from a small number of measures, such as species population estimates, obtained many years apart (e.g. see Brooke, Bonnaud, Dilley, Flint, Holmes, Jones, Provost, Rocamora, Ryan, Surman, et al., 2018). Apparent changes detected from repeated population estimates have catalysed invasive species eradication programmes (Brooke, Bonnaud, Dilley, Flint, Holmes, Jones, Provost, Rocamora, Ryan, \& Surman, 2018), informed fisheries and harvest management including influencing policy and international agreements (Agreement on the Conservation of Albatrosses and Petrels, 2001; Newman et al., 2009; Richard \& Abraham, 2013), been used to assess the outcomes of conservation interventions and enhance future ones (Bourgeois et al., 2013; Parker et al., 2015), and to inform Red List status 
assessments (Rodríguez et al., 2019). However, high uncertainty in petrel population estimates can hamper their ability to achieve and unambiguously inform these objectives. For example, Cory's equipment and survey design over successive attempts to estimate the population size (see Carlile et al., 2019; Lavers et al., 2019).

For a considerable majority of petrels obtaining accurate estimates is particularly difficult because nests cannot be counted directly. Instead they are hidden in crevices and underground burrows distributed heterogeneously across challenging terrain, and birds only return to or leave from their burrows at night (Rayner et al., 2007; Schumann et al., 2013; Warham, 1996). Uncertainty around petrel population estimates is inflated because variance around both the estimated number of burrows and the proportion of burrows occupied by breeding pairs is propagated when the two metrics are combined (Whitehead et al., 2014). Given the inherent uncertainties in petrel population estimates, and the debate around spending limited funds on undertaking conservation actions or gathering evidence to inform future actions (Brooke, Bonnaud, Dilley, Flint, Holmes, Jones, Provost, Rocamora, Ryan, \& Surman, 2018), it is important to know whether, and how much, the level of uncertainty in estimates matters.

We undertook a literature review and meta-analysis to: (i) understand the motivations for estimating population sizes for petrels, (ii) assess uncertainty in population estimates and correlates thereof; and (iii) evaluate the implications of uncertainty given the prevalent but potentially flawed 
population estimates has improved over time and assess whether there are clear steps that can be taken to minimise uncertainty in future estimates to improve management.

\section{METHODS}

\section{Approach}

Our study had two parts: (a) a review of published literature reporting estimates of petrel population sizes on islands to explore motivations for generating estimates, and (b) a meta-analysis of uncertainty in published population estimates. Throughout we restrict our review to petrels that nest underground. In our meta-analysis we conducted a simulation to understand the power for published estimates to detect population change given their reported uncertainty. To examine drivers of uncertainty, we investigated first whether the number of estimates being published has changed over time and if uncertainty is related to publishing trends, and then whether uncertainty can be explained by variables between estimates.

\section{Literature review}

We searched the Web of Science bibliographic index on 20 January 2020 (see Appendix S1 in the Supporting Information). Our structured search returned 900 studies. We screened all titles and abstracts for papers potentially reporting population or colony estimates for any of our target species (see Table S1 in the Supporting Information) from one or more islands, and then assessed full text articles, retaining all papers that reported quantitative estimates (Figure 1). After full screening, 68 studies were selected for review. All studies in the literature review and meta-analysis are available from the Data Availability Statement.

Before conducting our review, we gave prior consideration to the main reasons people might estimate petrel population sizes. For each reason we proposed a level of requisite certainty that 
estimates must attain to be fit-for-purpose (Table 1). During the review, for each paper containing a population estimate we recorded any mention of specific management actions the paper intended survey/population estimate.

\section{Meta-analysis}

We extracted published population estimates reported in each paper. Most reported a mean $(\mu)$, but where only minima or maxima were reported we used this as the estimate, and where only minima and maxima were reported we used their average as the estimate. If available, we extracted estimated: $C I=\mu \pm 1.96 \times \sigma_{\bar{x}}$. To compare reported uncertainty between studies we calculated the coefficient of variation (CV) as $\sigma_{\bar{x}} / \mu$.

We used simple simulations to assess the power to detect population declines from published population size $\left(N_{1}\right)$ for each case study, we first generated a sequence of annual true population sizes $\left(N_{t}\right)$ for declines of $30 \%, 50 \%$, and $80 \%$ over 3 generations $\left(t_{\max }\right)$ (following Bird et al., 2020; IUCN, 2012). These rates of decline, measured entirely in the past, in the past and future, or entirely in the future are thresholds for listing species as Vulnerable, Endangered and Critically Endangered on the IUCN Red List and correspond to rapid, very rapid and extremely rapid population declines (BirdLife International, 2020). Population declines were generated based upon an exponential rate of population change $\left(N_{t}=N_{1} * e^{r t}\right.$, where $r$ is the exponential rate of change) with no stochasticity. 
normal distribution with mean $N_{t}$ and variance approximated from the published confidence

intervals. For these simulations, we assumed a fixed coefficient of variation, such that variance

A number of sources contribute to uncertainty in petrel population estimates (Table S1, Supporting according to those that reported burrow and occupancy statistics and those that did not. Having derived the CV for each estimate (see above) we compared the means of these intervals between groups using t-tests, group trends in the size of normalised confidence intervals through time were assessed with linear regression, and trends in the proportion of studies reporting different variances were tested with Chi-squared tests of proportions. To allow analysis and identification of potential correlates of uncertainty we extracted additional variables reported with the published population estimates: the year of study/survey, body size and Red List status of the surveyed species, size of the island surveyed, and the survey methods used (Table 2). variables are beyond the control of managers it may be possible to use them to predict whether 
where further research might be focussed to reduce uncertainty (e.g. improving survey methods for large islands or small-bodied species).

We fitted a global linear model including all explanatory variables and the survey technique (Table 2) as fixed effects, study as a random effect, and normalized confidence intervals as the response to identify predictors of uncertainty. We then fitted simpler models consisting of all combinations of subsets of the explanatory variables and compared models using Akaike's Information Criterion (AIC). Candidate models were selected following Richards (2015). All models within 6 AIC of the preferred model (lowest AIC) were considered but a model was only included with the preferred model if there were no more parsimonious models with lower AIC. We also plotted bivariate relationships between normalised confidence limits and each explanatory variable and assessed their explanatory power using adjusted $R^{2}$ (continuous variables) or ANOVA (categorical variables). and Ime4 packages (Bates et al., 2015; R Core Team, 2020; Wickham et al., 2019).

\section{RESULTS}

\section{Literature review}

We identified 68 studies that reported 170 population estimates in total. Some studies reported more than one motivation for generating a population estimate. The motivations reported had all been identified a priori as reasons for generating estimates (Table 1), except for studies focussed on methods to improve estimates $(n=14)$. Assessing species status and trends by providing a baseline or comparison figure for trend estimates was the reported motivation for $51(75 \%)$ of 68 studies (Figure 2). For 87 (67\%) of the 129 estimates published in these 51 studies, a historic estimate for the same species and site was referenced, but in relation to only 47 estimates (under half) were these historic data used to assess population change. In the remaining 48 cases the paper reported 
that methodological differences precluded comparison between historic and contemporary estimates. Of the 42 cases where a comparison was made, on only one occasion was uncertainty around the reported change quantified.

Four studies containing 12 estimates did not mention any reason for generating the estimates, and no studies reported collecting estimates to inform $1 \%$ population thresholds, to assess whether functional roles are being filled, or specifically for public outreach.

Meta-analysis

Quantitative meta-analyses were restricted to 106 estimates from 44 studies that either had a confidence interval or reported dispersion statistics which we used to approximate a confidence interval. The mean $\mathrm{CV}$ of these estimates was $0.17(\mathrm{SD}=0.14)$.

For each of 106 population estimates with reported or approximated confidence intervals, we determined the minimum time between samples required for a statistically significant difference in population size to be detected for simulated declines of $30 \%, 50 \%$, and $80 \%$ over 3 generations (Figure S1, Supporting Information). This is equivalent to measuring the minimum decline between samples that can be detected. We found that if populations were re-surveyed after 10 years, only $52 \%$ of studies could detect a change in a population declining at an annual rate consistent with $80 \%$ decline over three generations, $20 \%$ could detect changes in a population declining at an annual rate consistent with $50 \%$ decline over three generations, and just $5 \%$ of studies could detect changes in a population declining at an annual rate consistent with $30 \%$ decline over three generations (Figure 3 ). 
242 The number of studies publishing population estimates (Figure S2, Supporting Information) and the proportion of them that also report uncertainty have both increased over time (Figure 4). Surprisingly, the magnitude of uncertainty in overall population estimates has also increased over time. We found no evidence that the proportion of studies that report key underlying parameters of most estimates, burrow numbers and burrow occupancy, has increased (Figure 4 and Figure S3 in Supporting Information). Reporting of both parameters is low. Of those studies that do report burrow numbers and burrow occupancy $76 \%$ and $33 \%$ respectively report uncertainty around these parameters and there is no evidence that these proportions have increased. Overall, uncertainty was significantly higher when estimating burrow numbers than burrow occupancy (Figure 4). We found some evidence that inspection hatches result in lower uncertainty than playback when estimating burrow occupancy, and that transects resulted in lower uncertainty than plots when estimating burrow numbers, but there were no significant differences between other methods reported with no explanatory variables, provided the best fit to the data (Table S4 in Supporting Information). Plotting the bivariate relationships supports this result with the only significant correlates of CV being population size and year of estimate, although the relationships were both weak (population size: $R^{2}=0.065$; year of estimate: $\left.R^{2}=0.04\right)$. We found no influence of species body mass, island size, Red List status or the survey method used (Figure 5 and Table S5 in Supporting Information). Thus, our analysis could not demonstrate that certainty in estimates is improving through time, or that 


\section{DISCUSSION}

268

The most common motivation for estimating petrel populations on islands is to inform species status and trend assessments, yet we have shown that the uncertainty around these estimates makes it unlikely that population changes exceeding significant management thresholds could be detected with confidence within typical management timeframes. This suggests that most population estimates cannot reliably inform the management decisions, such as resource allocation and conservation intervention, for which they are intended.

Just over half of the studies we reviewed compared estimates collected at two different times. Of those, most stated that historic estimates were of insufficient quality for a meaningful comparison to be made, with the implicit assertion that the contemporary estimates would now act as a suitable baseline for future comparison. Our results suggest that this implicit assertion may be misplaced. Old sampling designs are often discarded in favour of new ones without adequate thought as to whether the new design is more repeatable and more reliable. The simulation highlighted that after ten years, and under a simplified scenario of no population stochasticity, population declines equivalent to $30 \%$ over three generations, the threshold for listing species as Vulnerable on the IUCN Red List, could only be detected in $5 \%$ of cases. We stress too that this is merely the detection of a significant difference between two estimates. It does not confirm the magnitude of change that has occurred. In a more realistic scenario of population stochasticity and uncertain variance, even steeper declines would need to occur before a change could be reliably detected. While our simulation was based upon a comparison between estimates at two time points, and it is well known that power could be enhanced by more frequent sampling (Buxton et al., 2016), this is representative of the reality on many islands where petrel surveys may be repeated decades apart using different methodologies.

Our findings support the conclusions of focussed single-species or regional studies that current approaches to repeat surveys are likely failing to detect changes and that only very large changes in 
population size can be detected reliably (Arneill et al., 2019; Hatch, 2003; D. R. Sutherland \& Dann, (see Buxton et al., 2016).

\section{Are population estimates always warranted?}

Almost universally the opening sentiments of studies we reviewed highlight the need for "robust",

"accurate", "precise" population estimates, describing them as "fundamental", "key", or "crucial" for conservation, determining trends and informing management (e.g. Arneill et al., 2019; Lavers et al., 2019; Pearson et al., 2013; Sutherland and Dann, 2012; Whitehead et al., 2014). Whether estimates really are warranted depends first on what they are intended for, and second on whether they can achieve the level of certainty required for that stated aim. As is common for biodiversity monitoring 
(Defos du Rau et al., 2015; Newman et al., 2009; Rexer-Huber et al., 2017), many did not. Brooke et conservation interventions. Similarly, population estimates are useful when they can be linked to clear policy mechanisms such as the Agreement on the Conservation of Albatrosses and Petrels that use population estimates and trends to inform management (Agreement on the Conservation of Albatrosses and Petrels, 2001). However, the collection of estimates because seabirds are ecosystem indicators seems tenuous. Population data for Antarctic Petrels Fulmaris glaciodes and Cape Petrels Daption capensis can be used in fisheries management by the Convention on the Conservation of Antarctic Marine Living Resources (CCAMLR) Ecosystem Monitoring Program (Agnew, 1997; Descamps et al., 2016), but species captured in our review currently lack equivalent linkages to policy and management.

By clearly articulating their objectives for generating a population estimate, studies can determine the level of acceptable uncertainty (Possingham et al., 2012; Runge et al., 2011). For petrels, survey inevitably be low. It is important that studies do optimise their design given the available resources (both financial and informational), and then carefully and objectively review the potential value of generating a population estimate given the level of uncertainty likely in the result. A significant challenge is that published recommendations are dispersed across a broad literature which can be difficult to access (Poisot et al., 2019). Whereas the emergence of evidence-based conservation as a pillar of conservation science has been supported by projects collating and synthesising evidence to inform management (W. J. Sutherland \& Wordley, 2017), no equivalent projects yet collate and synthesise monitoring methods - the basis for the collection of evidence. 
341 Fundamentally, not all reasons for estimating petrel populations demand high levels of precision, but for those that do it is important to objectively assess whether they can be achieved given available resources. If not, resources should either be increased if there is value in doing so, or no attempt should be made to estimate the population.

\section{Directions for future research}

347 An effective way to build on our a priori assessment of uncertainty tolerances would be to conduct a stakeholder-driven value of information analysis to quantify the value of reducing uncertainty in population estimates depending on their intended uses (Canessa et al., 2015; Runge et al., 2011).

There is also a need to better understand when and how population estimates can be improved.

We found that the rate of publication of petrel population estimates has increased through time. More people are tackling the issue of how to estimate petrel populations, and more research is benefitting from peer review, but it remains a fundamentally challenging system to study. Our metaanalysis suggests uncertainty has actually increased through time despite the emergence of modern technologies and advances in statistical methods (Langrock \& Borchers, 2017), although this finding probably reflects poor reporting of early estimates which, if not explicit about uncertainty, were excluded from analysis. While uncertainty may not have been reduced, bias very likely has. Whereas old estimates were more likely to employ biased survey methods like targeted searches, and were designs, and they are more likely to report uncertainty.

We also found that none of the variables we tested were reliable predictors of the overall level of uncertainty in each study. As a result, there are no easy guidelines around species and geographic 
undertaking population estimates, hence the importance of considering whether generating an estimate warrants the effort required. minimise variance around burrow density and uncertainty in overall numbers (Appendix S5 in Supporting Information). In terms of occupancy, in some cases, uncertainty may have been estimated and may be factored into the final population estimate, just not reported explicitly in the paper, but in many cases it appears not to have been considered. We recommend sampling occupancy in a number of plots and calculating variance between occupancy rates in all plots so that an overall estimate of the spread of sample means can be generated and confidence intervals reported, or failing that the binomial confidence interval of a proportion is calculated.

We found evidence that mean normalized confidence intervals differed between occupancy methods (Figure S4 and Table S3 in Supporting Information). Other studies allude to the differences in accuracy between different methods of assessing burrow occupancy, but this warrants a quantitative review - something that is only possible if studies report their uncertainty. There is no reason why user-centred design cannot further improve precision around occupancy, ideally eliminating uncertainty through the use of ongoing technological developments.

\section{Conclusions}

Estimates of petrel populations are commonly made to inform trend and threat assessments, but they currently perform rather poorly in this role. Therefore it might be appropriate to focus research on parameters better able to inform management such as productivity and survival (Caravaggi et al., 
While population estimates are used in various ways (Table 1 ) only really when small populations are compared against criteria thresholds for status assessments and when informing $1 \%$ thresholds is the actual estimate important. In other cases alternative metrics may be more appropriate.

391 Further methodological improvements could reduce uncertainty, particularly uncertainty around burrow occupancy, but potential gains are finite, and past history suggests that improvement over time is not inevitable or necessarily very rapid. Based on our experience examining historic datasets on multiple species of petrels and undertaking field surveys for contemporary estimates, and now this work, we encourage others to report methods, results and uncertainty clearly and fully to ensure estimates are used appropriately, and to enable further improvements in population estimation. To ensure the best use of conservation funds it is worth considering why a population estimate is being generated, and giving prior consideration to whether the final estimate is likely to achieve a sufficient level of certainty. 
401 We would like to thank Simon Wotherspoon, for advice on the analysis, and Holly Jones, the

402 Associate Editor and two anonymous referees for extremely valuable comments and advice for

403 improving the manuscript. JB was supported by a Research Training Program scholarship, an

404 Antarctic Science International Bursary, National Environmental Science Programme Threatened

405 Species Recovery Hub Research Support and a BirdLife Australia Stuart Leslie Bird Research Award.

406 BW was supported by a Postdoctoral Fellowship from the Natural Sciences and Engineering Research

407 Council of Canada and ARC Linkage Project LP150101059 (awarded to RF).

408

409

DATA AVAILABILITY STATEMENT

410 All data and R code are available from the Australian Antarctic Data Centre:

411 doi:10.4225/15/5282F113C4277. 


\section{REFERENCES}

Agreement on the Conservation of Albatrosses and Petrels, (2001). https://acap.aq/acapagreement/206-agreement-on-the-conservation-of-albatrosses-and-petrels/file

Agnew, D. J. (1997). Review -The CCAMLR Ecosystem Monitoring Programme. Antarctic Science, 9(3), 235-242. https://doi.org/10.1017/\$095410209700031X

Albores-Barajas, Y. V., Soldatini, C., Ramos-Rodríguez, A., Alcala-Santoyo, J. E., Carmona, R., \& Dell'Omo, G. (2018). A new use of technology to solve an old problem: Estimating the population size of a burrow nesting seabird. PLOS ONE, 13(9), e0202094. https://doi.org/10.1371/journal.pone.0202094

Arneill, G. E., Perrins, C. M., Wood, M. J., Murphy, D., Pisani, L., Jessopp, M. J., \& Quinn, J. L. (2019). Sampling strategies for species with high breeding-site fidelity: A case study in burrownesting seabirds. PLOS ONE, 14(8), e0221625. https://doi.org/10.1371/journal.pone.0221625

Barbraud, C., Marteau, C., Ridoux, V., Delord, K., \& Weimerskirch, H. (2008). Demographic response of a population of white-chinned petrels Procellaria aequinoctialis to climate and longline fishery bycatch. Journal of Applied Ecology, 45(5), 1460-1467. https://doi.org/10.1111/j.1365-2664.2008.01537.

Bates, D., Mächler, M., Bolker, B., \& Walker, S. (2015). Fitting Linear Mixed-Effects Models Using Ime4. Journal of Statistical Software, 67(1). https://doi.org/10.18637/jss.v067.i01

Bird, J. P., Martin, R., Akçakaya, H. R., Gilroy, J., Burfield, I. J., Garnett, S. T., Symes, A., Taylor, J., Şekercioğlu, Ç. H., \& Butchart, S. H. M. (2020). Generation lengths of the world's birds and their implications for extinction risk. Conservation Biology, cobi.13486. https://doi.org/10.1111/cobi.13486

Bird, J. P., Varnham, K., Shaw, J., \& Holmes, N. D. (2019). Practical considerations for monitoring invasive mammal eradication outcomes. In C. R. Veitch, M. N. Clout, A. R. Martin, J. C. Russell, \& C. J. West (Eds.), Island invasives: Scaling up to meet the challenge. Proceedings of 
the international conference on island invasives 2017 (pp. 545-551). IUCN, International Union for Conservation of Nature. https://doi.org/10.2305/IUCN.CH.2019.SSC-OP.62.en

BirdLife International. (2020). IUCN Red List for birds. Downloaded from http://www. birdlife.org on $22 / 06 / 2020$.

Bourgeois, K., Ouni, R., Pascal, M., Dromzée, S., Fourcy, D., \& Abiadh, A. (2013). Dramatic increase in the Zembretta Yelkouan shearwater breeding population following ship rat eradication spurs interest in managing a 1500-year old invasion. Biological Invasions, 15(3), 475-482. https://doi.org/10.1007/s10530-013-0419-x

Brooke, M. de L., Bonnaud, E., Dilley, B. J., Flint, E. N., Holmes, N. D., Jones, H. P., Provost, P., Rocamora, G., Ryan, P. G., \& Surman, C. (2018). Enhancing the value of future island eradications needs improved understanding of past outcomes. Animal Conservation, 21(1), $19-20$.

Brooke, M. de L., Bonnaud, E., Dilley, B. J., Flint, E. N., Holmes, N. D., Jones, H. P., Provost, P., Rocamora, G., Ryan, P. G., Surman, C., \& Buxton, R. T. (2018). Seabird population changes following mammal eradications on islands. Animal Conservation, 21(1), 3-12. https://doi.org/10.1111/acv.12344

Buxton, R. T., Gormley, A. M., Jones, C. J., \& Lyver, P. O. (2016). Monitoring burrowing petrel populations: A sampling scheme for the management of an island keystone species. The Journal of Wildlife Management, 80(1), 149-161. https://doi.org/10.1002/jwmg.994

Canessa, S., Guillera-Arroita, G., Lahoz-Monfort, J. J., Southwell, D. M., Armstrong, D. P., Chadès, I., Lacy, R. C., \& Converse, S. J. (2015). When do we need more data? A primer on calculating the value of information for applied ecologists. Methods in Ecology and Evolution, 6(10), 1219-1228. https://doi.org/10.1111/2041-210X.12423

Caravaggi, A., Cuthbert, R. J., Ryan, P. G., Cooper, J., \& Bond, A. L. (2019). The impacts of introduced House Mice on the breeding success of nesting seabirds on Gough Island. Ibis, 161(3), 648661. https://doi.org/10.1111/ibi.12664 
Carlile, N., Priddel, D., Reid, T., \& Fullagar, P. (2019). Flesh-footed shearwater decline on Lord Howe: Rebuttal to Lavers et al. 2019. Global Ecology and Conservation, 20, e00794. https://doi.org/10.1016/j.gecco.2019.e00794

Clark, T. J., Matthiopoulos, J., Bonnet-Lebrun, A.-S., Campioni, L., Catry, P., Marengo, I., Poncet, S., \& Wakefield, E. (2019). Integrating habitat and partial survey data to estimate the regional population of a globally declining seabird species, the sooty shearwater. Global Ecology and Conservation, 17, e00554. https://doi.org/10.1016/j.gecco.2019.e00554

Clemens, R. S., Weston, M. A., Haslem, A., Silcocks, A., \& Ferris, J. (2010). Identification of significant shorebird areas: Thresholds and criteria. Diversity and Distributions, 16(2), 229-242. https://doi.org/10.1111/j.1472-4642.2009.00635.x

Croxall, J. P., Butchart, S. H., Lascelles, B. E. N., Stattersfield, A. J., Sullivan, B. E. N., Symes, A., \& Taylor, P. (2012). Seabird conservation status, threats and priority actions: A global assessment. Bird Conservation International, 22(1), 1-34.

Cuthbert, R. (2004). Breeding biology of the Atlantic Petrel, Pterodroma incerta, and a population estimate of this and other burrowing petrels on Gough Island, South Atlantic Ocean. EmuAustral Ornithology, 104(3), 221-228.

Danckwerts, D. K., McQuaid, C. D., Jaeger, A., McGregor, G. K., Dwight, R., Le Corre, M., \& Jaquemet, S. (2014). Biomass consumption by breeding seabirds in the western Indian Ocean: Indirect interactions with fisheries and implications for management. ICES Journal of Marine Science, 71(9), 2589-2598. https://doi.org/10.1093/icesjms/fsu093

Defos du Rau, P., Bourgeois, K., Thévenet, M., Ruffino, L., Dromzée, S., Ouni, R., Abiadh, A., Estève, R., Durand, J.-P., Anselme, L., Faggio, G., Yahya, J. M., Rguibi, H., Renda, M., Miladi, B., Hamrouni, H., Alilech, S., Nefla, A., Jaouadi, W., ... Renou, S. (2015). Reassessment of the size of the Scopoli's Shearwater population at its main breeding site resulted in a tenfold increase: Implications for the species conservation. Journal of Ornithology, 156(4), 877-892. https://doi.org/10.1007/s10336-015-1187-4 
Descamps, S., Tarroux, A., Cherel, Y., Delord, K., Godø, O. R., Kato, A., Krafft, B. A., Lorentsen, S.-H., Ropert-Coudert, Y., Skaret, G., \& Varpe, $\varnothing$. (2016). At-Sea Distribution and Prey Selection of Antarctic Petrels and Commercial Krill Fisheries. PLOS ONE, 11(8), e0156968. https://doi.org/10.1371/journal.pone.0156968

Dilley, B. J., Davies, D., Schramm, M., Connan, M., \& Ryan, P. G. (2017). The distribution and abundance of Blue Petrels (Halobaena caerulea) breeding at subantarctic Marion Island. Emu-Austral Ornithology, 1-11.

Dilley, B. J., Schoombie, S., Stevens, K., Davies, D., Perold, V., Osborne, A., Schoombie, J., Brink, C. W., Carpenter-Kling, T., \& Ryan, P. G. (2018). Mouse predation affects breeding success of burrow-nesting petrels at sub-Antarctic Marion Island. Antarctic Science, 30(2), 93-104. https://doi.org/10.1017/\$0954102017000487

Dyer, P. K., \& Hill, G. J. E. (1991). A solution to the problem of determining the occupancy status of wedge-tailed shearwater Puffinus pacificus burrows. Emu, 91(1), 20-25.

Fischer, A., Bednar-Friedl, B., Langers, F., Dobrovodská, M., Geamana, N., Skogen, K., \& Dumortier, M. (2011). Universal criteria for species conservation priorities? Findings from a survey of public views across Europe. Biological Conservation, 144(3), 998-1007. https://doi.org/10.1016/j.biocon.2010.12.004

Fischer, J., Debski, I., Taylor, G., \& Wittmer, H. (2017). Assessing the suitability of non-invasive methods to monitor interspecific interactions and breeding biology of the South Georgian diving petrel (Pelecanoides georgicus). Notornis, 64(1), 13-20.

Graham, N. A. J., Wilson, S. K., Carr, P., Hoey, A. S., Jennings, S., \& MacNeil, M. A. (2018). Seabirds enhance coral reef productivity and functioning in the absence of invasive rats. Nature, 559(7713), 250-253. https://doi.org/10.1038/s41586-018-0202-3

Hansen, B. D., Fuller, R. A., Watkins, D., Rogers, D. I., Clemens, R. S., Woehler, E. J., \& Weller, D. R. (2016). Revision of the East Asian-Australasian Flyway Population Estimates for 37 listed 
Migratory Shorebird Species (p. 90). Unpublished report for the Department of the Environment. BirdLife Australia.

Hatch, S. A. (2003). Statistical power for detecting trends with applications to seabird monitoring. Biological Conservation, 111(3), 317-329.

IUCN. (2012). IUCN Red List Categories \& Criteria. Version IUCN Red List Categories and Criteria: Version 3.1. Second edition. Gland, Switzerland and Cambridge, UK: IUCN. iv + 32pp.3.1 Second edition.

IUCN. (2016). A Global Standard for the Identification of Key Biodiversity Areas, Version 1.0. First edition. Gland, Switzerland: IUCN.

IUCN. (2019). Guidelines for Using the IUCN Red List Categories and Criteria. Version 13. Prepared by the Standards and Petitions Subcommittee. Downloadable from http://www.iucnredlist.org/documents/RedListGuidelines.pdf.

Jones, H. P., Holmes, N. D., Butchart, S. H. M., Tershy, B. R., Kappes, P. J., Corkery, I., Aguirre-Muñoz, A., Armstrong, D. P., Bonnaud, E., Burbidge, A. A., Campbell, K., Courchamp, F., Cowan, P. E., Cuthbert, R. J., Ebbert, S., Genovesi, P., Howald, G. R., Keitt, B. S., Kress, S. W., ... Croll, D. A. (2016). Invasive mammal eradication on islands results in substantial conservation gains. Proceedings of the National Academy of Sciences, 113(15), 4033-4038. https://doi.org/10.1073/pnas.1521179113 Langrock, R., \& Borchers, D. L. (2017). Guest editors' introduction to the special issue on “Ecological Statistics." AStA Advances in Statistical Analysis, 101(4), 345-347. https://doi.org/10.1007/s10182-017-0307-2

Lavers, J. L., Hutton, I., \& Bond, A. L. (2019). Changes in technology and imperfect detection of nest contents impedes reliable estimates of population trends in burrowing seabirds. Global Ecology and Conservation, 17, e00579. https://doi.org/10.1016/j.gecco.2019.e00579 
Lawton, K., Robertson, G., Kirkwood, R., Valencia, J., Schlatter, R., \& Smith, D. (2006). An estimate of population sizes of burrowing seabirds at the Diego Ramirez archipelago, Chile, using distance sampling and burrow-scoping. Polar Biology, 29(3), 229-238.

Mackenzie, D. I., \& Royle, J. A. (2005). Designing occupancy studies: General advice and allocating survey effort. Journal of Applied Ecology, 42(6), 1105-1114. https://doi.org/10.1111/j.13652664.2005.01098.x

Madeiros, J., Carlile, N., \& Priddel, D. (2012). Breeding biology and population increase of the Endangered Bermuda Petrel Pterodroma cahow. Bird Conservation International, 22(1), 3545. https://doi.org/10.1017/\$0959270911000396

Martinez-Gomez, J. E., \& Jacobsen, J. K. (2004). The conservation status of Townsend's shearwater Puffinus auricularis auricularis. Biological Conservation, 116(1), 35-47. https://doi.org/10.1016/S0006-3207(03)00171-X

Martín-López, B., González, J. A., \& Montes, C. (2011). The pitfall-trap of species conservation priority setting. Biodiversity and Conservation, 20(3), 663-682.

Militão, T., Dinis, H. A., Zango, L., Calabuig, P., Stefan, L. M., \& González-Solís, J. (2017). Population size, breeding biology and on-land threats of Cape Verde petrel (Pterodroma feae) in Fogo Island, Cape Verde. PLOS ONE, 12(4), e0174803. https://doi.org/10.1371/journal.pone.0174803

Moher, D., Liberati, A., Tetzlaff, J., Altman, D. G., \& Group, P. (2009). Preferred reporting items for systematic reviews and meta-analyses: The PRISMA statement. PLoS Med, 6(7), e1000097. Newman, J., Scott, D., Bragg, C., McKechnie, S., Moller, H., \& Fletcher, D. (2009). Estimating regional population size and annual harvest intensity of the sooty shearwater in New Zealand. New Zealand Journal of Zoology, 36(3), 307-323. https://doi.org/10.1080/03014220909510157 Nichols, J. D., Runge, M. C., Johnson, F. A., \& Williams, B. K. (2007). Adaptive harvest management of North American waterfowl populations: A brief history and future prospects. Journal of Ornithology, 148(S2), 343-349. https://doi.org/10.1007/s10336-007-0256-8 
Olivier, F., \& Wotherspoon, S. J. (2006). Distribution and abundance of Wilson's storm petrels Oceanites oceanicus at two locations in East Antarctica: Testing habitat selection models. Polar Biology, 29(10), 878-892. https://doi.org/10.1007/s00300-006-0127-4

Oppel, S., Hervias, S., Oliveira, N., Pipa, T., Silva, C., Geraldes, P., Goh, M., Immler, E., \& McKown, M. (2014). Estimating population size of a nocturnal burrow-nesting seabird using acoustic monitoring and habitat mapping. Nature Conservation, 7, 1-13. https://doi.org/10.3897/natureconservation.7.6890

Oppel, S., Lavers, J. L., Donaldson, A. H., Forrest, A. K., McClelland, G. T. W., Bond, A. L., \& Brooke, M. de L. (2017). Population status, breeding success and ecology of the Henderson Petrel after a failed rat eradication on Henderson Island. Emu - Austral Ornithology, 117(2), 151-159. https://doi.org/10.1080/01584197.2017.1292610

Otero, X. L., De La Peña-Lastra, S., Pérez-Alberti, A., Ferreira, T. O., \& Huerta-Diaz, M. A. (2018). Seabird colonies as important global drivers in the nitrogen and phosphorus cycles. Nature Communications, 9(1), 246. https://doi.org/10.1038/s41467-017-02446-8

Parker, G. C., Rexer-Huber, K., \& Thompson, D. (2015). Are grey petrels returning to Campbell Island? Survey and census 14 years after rodent eradication. http://www.doc.govt.nz/Documents/conservation/marine-and-coastal/marineconservation-services/meetings/csp-twg-draft-grey\%20petrel-survey-background-report.pdf Parker, G. C., Rexer-Huber, K., \& Thompson, D. (2017). Grey petrel population on Campbell Island 14 years after rodent eradication. Antarctic Science, 29(3), 209-216. https://doi.org/10.1017/S0954102016000626

Pearson, S. F., Hodum, P. J., Good, T. P., Schrimpf, M., \& Knapp, S. M. (2013). A Model Approach for Estimating Colony Size, Trends, and Habitat Associations of Burrow-Nesting Seabirds. The Condor, 115(2), 356-365. https://doi.org/10.1525/cond.2013.110207

Perry, N. (2010). The ecological importance of species and the Noah's Ark problem. Ecological Economics, 69(3), 478-485. 
Poisot, T., Bruneau, A., Gonzalez, A., Gravel, D., \& Peres-Neto, P. (2019). Ecological Data Should Not Be So Hard to Find and Reuse. Trends in Ecology \& Evolution, 34(6), 494-496. https://doi.org/10.1016/j.tree.2019.04.005

Possingham, H. P., Andelman, S. J., Burgman, M. A., Medellín, R. A., Master, L. L., \& Keith, D. A. (2002). Limits to the use of threatened species lists. Trends in Ecology \& Evolution, 17(11), 503-507.

Possingham, H. P., Wintle, B. A., Fuller, R. A., \& Joseph, L. N. (2012). The conservation return on investment from ecological monitoring. Biodiversity Monitoring in Australia, 49-58.

Pressey, R. L., Cabeza, M., Watts, M. E., Cowling, R. M., \& Wilson, K. A. (2007). Conservation planning in a changing world. Trends in Ecology \& Evolution, 22(11), 583-592. https://doi.org/10.1016/j.tree.2007.10.001

R Core Team. (2020). R: A language and environment for statistical computing. R Foundation for Statistical Computing, Vienna, Austria. URL Https://Www.R-Project.Org/.

Ramsar. (2016). An Introduction to the Convention on Wetlands (previously The Ramsar Convention Manual). Ramsar Convention Secretariat, Gland, Switzerland.

Rayner, M. J., Clout, M. N., Stamp, R. K., Imber, M. J., Brunton, D. H., \& Hauber, M. E. (2007). Predictive habitat modelling for the population census of a burrowing seabird: A study of the endangered Cook's petrel. Biological Conservation, 138(1-2), 235-247. https://doi.org/10.1016/j.biocon.2007.04.021

Rexer-Huber, K., Parker, G. C., Sagar, P. M., \& Thompson, D. R. (2017). White-chinned petrel population estimate, Disappointment Island (Auckland Islands). Polar Biology, 4O(5), 10531061.

Richard, Y., \& Abraham, E. R. (2013). Application for Potential Biological Removal Methods to Seabird Populations. Ministry for Primary Industries. 
Richards, S. A. (2015). Likelihood and model selection. In G. A. Fox, S. Negrete-Yankelevich, \& V. J.

Sosa (Eds.), Ecological Statistics (pp. 58-80). Oxford University Press.

https://doi.org/10.1093/acprof:oso/9780199672547.003.0004

Rodrigues, A., Pilgrim, J., Lamoreux, J., Hoffmann, M., \& Brooks, T. (2006). The value of the IUCN Red

List for conservation. Trends in Ecology \& Evolution, 21(2), 71-76.

https://doi.org/10.1016/j.tree.2005.10.010

Rodríguez, A., Arcos, J. M., Bretagnolle, V., Dias, M. P., Holmes, N. D., Louzao, M., Provencher, J.,

Raine, A. F., Ramírez, F., Rodríguez, B., Ronconi, R. A., Taylor, R. S., Bonnaud, E., Borrelle, S.

B., Cortés, V., Descamps, S., Friesen, V. L., Genovart, M., Hedd, A., ... Chiaradia, A. (2019).

Future Directions in Conservation Research on Petrels and Shearwaters. Frontiers in Marine

Science, 6. https://doi.org/10.3389/fmars.2019.00094

Runge, M. C., Converse, S. J., \& Lyons, J. E. (2011). Which uncertainty? Using expert elicitation and expected value of information to design an adaptive program. Biological Conservation, 144(4), 1214-1223.

Schumann, N., Dann, P., Hoskins, A. J., \& Arnould, J. P. Y. (2013). Optimizing survey effort for burrownesting seabirds. Journal of Field Ornithology, 84(1), 69-85.

Sinclair, J. C. (1981). Techniques for observing subantarctic burrowing petrels at the nest. Marine Ornithology, 9, 67-72.

Sutherland, D. R., \& Dann, P. (2012). Improving the accuracy of population size estimates for burrownesting seabirds: Population size in nesting seabirds. Ibis, 154(3), 488-498. https://doi.org/10.1111/j.1474-919X.2012.01234.x

Sutherland, W. J., \& Wordley, C. F. (2017). Evidence complacency hampers conservation. Nature Ecology \& Evolution, 1(9), 1215.

Thompson, W. (2013). Sampling Rare or Elusive Species: Concepts, Designs, and Techniques for Estimating Population Parameters. Island Press. 
Warham, J. (1996). The behaviour, population biology and physiology of the petrels. Academic Press. https://books.google.co.uk/books?hl=en\&lr=\&id=HzOFrKzXrwQC\&oi=fnd\&pg=PP1\&dq=warh am+1996+petrels\&ots=LJqKOZOq4a\&sig=gRqme_hYvYMcn5nGE-DvQJi3_80

Whitehead, A. L., Lyver, P. O., Jones, C. J., Bellingham, P. J., MacLeod, C. J., Coleman, M., Karl, B. J., Drew, K., Pairman, D., Gormley, A. M., \& others. (2014). Establishing accurate baseline estimates of breeding populations of a burrowing seabird, the grey-faced petrel (Pterodroma macroptera gouldi) in New Zealand. Biological Conservation, 169, 109-116.

Wickham, H., Averick, M., Bryan, J., Chang, W., McGowan, L. D., François, R., Grolemund, G., Hayes, A., Henry, L., Hester, J., Kuhn, M., Pedersen, T. L., Miller, E., Bache, S. M., Müller, K., Ooms, J., Robinson, D., Seidel, D. P., Spinu, V., ... Yutani, H. (2019). Welcome to the Tidyverse. Journal of Open Source Software, 4(43), 1686. https://doi.org/10.21105/joss.01686

Wood, G., \& Otley, H. (2013). An assessment of the breeding range, colony sizes and population of the Westland petrel ( Procellaria westlandica ). New Zealand Journal of Zoology, 40(3), 186195. https://doi.org/10.1080/03014223.2012.736394 
bioRxiv preprint doi: https://doi org/101101/2021.04.07.438872; this version posted April 9, 2021. The copyright holder for this preprint (which was not certified by peer review) is the author/funder, who has granted bioRxiv a license to display the preprint in perpetuity. It is made available under aCC-BY-NC-ND 4.0 International license.

Table 1: Reasons to estimate petrel populations and required certainty identified a priori. We ranked required certainty based on our interpretation of the financial, societal and conservation implications of incorrect data.

\begin{tabular}{|c|c|c|c|}
\hline Reason for estimate & Explanation & Example sources & Required certainty \\
\hline a) Status - trends & $\begin{array}{l}\text { Triggers legislation, funding and } \\
\text { potentially management actions }\end{array}$ & $\begin{array}{l}\text { (Martinez-Gomez \& } \\
\text { Jacobsen, 2004; } \\
\text { Oppel et al., 2017) }\end{array}$ & High \\
\hline $\begin{array}{l}\text { b) Status - population } \\
\text { size }\end{array}$ & $\begin{array}{l}\text { Triggers legislation, funding and } \\
\text { potentially management actions, but only } \\
\text { relevant for low population sizes }\end{array}$ & $\begin{array}{l}\text { (Madeiros et al., } \\
\text { 2012; Militão et al., } \\
\text { 2017) }\end{array}$ & $\begin{array}{l}\text { Small pop's = High } \\
\text { Other = NA }\end{array}$ \\
\hline $\begin{array}{l}\text { c) Assessing impacts } \\
\text { of threats }\end{array}$ & $\begin{array}{l}\text { Can trigger legislation and management } \\
\text { actions. E.g. in relation to fisheries } \\
\text { bycatch and harvest management }\end{array}$ & $\begin{array}{l}\text { (Barbraud et al., } \\
\text { 2008; Newman et } \\
\text { al., 2009; Rexer- } \\
\text { Huber et al., 2017) } \\
\end{array}$ & High \\
\hline $\begin{array}{l}\text { d) Ecosystem } \\
\text { indicator }\end{array}$ & $\begin{array}{l}\text { Often cited, but rarely clear how species } \\
\text { populations quantifiably relate to other } \\
\text { ecosystem variables and how estimates } \\
\text { inform wider actions }\end{array}$ & $\begin{array}{l}\text { (Clark et al., 2019; } \\
\text { Olivier \& } \\
\text { Wotherspoon, } \\
\text { 2006; Whitehead et } \\
\text { al., 2014) }\end{array}$ & NA \\
\hline $\begin{array}{l}\text { e) Assessing impacts } \\
\text { of conservation } \\
\text { actions }\end{array}$ & $\begin{array}{l}\text { Informs return on investment and } \\
\text { provides an evidence base for future } \\
\text { conservation interventions }\end{array}$ & $\begin{array}{l}\text { (Brooke, Bonnaud, } \\
\text { Dilley, Flint, } \\
\text { Holmes, Jones, } \\
\text { Provost, Rocamora, } \\
\text { Ryan, \& Surman, } \\
\text { 2018; Brooke, } \\
\text { Bonnaud, Dilley, } \\
\text { Flint, Holmes, } \\
\text { Jones, Provost, } \\
\text { Rocamora, Ryan, } \\
\text { Surman, et al., } \\
\text { 2018) }\end{array}$ & Medium \\
\hline $\begin{array}{l}\text { f) Setting } 1 \% \\
\text { thresholds }\end{array}$ & $\begin{array}{l}\text { Common in national and international } \\
\text { legislation/site designation. Threshold of } \\
\text { overall population requiring whole-of- } \\
\text { range assessment. Triggers development } \\
\text { legislation and site protection }\end{array}$ & $\begin{array}{l}\text { (Clemens et al., } \\
\text { 2010; Hansen et al., } \\
\text { 2016) }\end{array}$ & Medium \\
\hline g) Functional role & $\begin{array}{l}\text { Species may have important Indirect Use } \\
\text { Values such as nutrient transfer and prey } \\
\text { regulation for which population size may } \\
\text { be a proxy }\end{array}$ & (Perry, 2010) & Low \\
\hline h) Public outreach & $\begin{array}{l}\text { Important leverage for funding and } \\
\text { political will }\end{array}$ & $\begin{array}{l}\text { (A. Fischer et al., } \\
\text { 2011) }\end{array}$ & Low \\
\hline
\end{tabular}


Table 2: Variables recorded during literature review

\begin{tabular}{|c|c|c|}
\hline Methods & \multicolumn{2}{|l|}{ Description } \\
\hline Survey technique & \multicolumn{2}{|c|}{$\begin{array}{l}\text { Categories following Rayner et al. (2007): mark recapture; direct counts of burrows within known colony locations; simple models } \\
\text { employing randomised burrow surveys and extrapolation of burrow densities across the total area available; habitat-area models } \\
\text { employing randomised burrow surveys and extrapolation of burrow densities across selected locations or designated habitat types. } \\
\text { Additional categories: advanced habitat-area models that used randomised burrow surveys and extrapolation of burrows based upon } \\
\text { multiple environmental variables rather than simple habitat layers; informed guess (not included in the meta-analysis). }\end{array}$} \\
\hline $\begin{array}{l}\text { Estimating burrow } \\
\text { numbers/density }\end{array}$ & \multicolumn{2}{|c|}{$\begin{array}{l}\text { Aerial photography (Albores-Barajas et al., 2018); strip transects (e.g. Parker et al., 2017); plots (e.g. Buxton et al., 2016); distance } \\
\text { sampling (e.g. Lawton et al., 2006); or direct searching of a whole area (e.g. Wood and Otley, 2013) }\end{array}$} \\
\hline Occupancy method & \multicolumn{2}{|c|}{$\begin{array}{l}\text { Burrowscope (e.g. Dyer \& Hill, 1991); grubbing (e.g. Sinclair, 1981); observation hatches (e.g. Dilley et al., 2017); palisades (e.g. J. } \\
\text { Fischer et al., 2017); call playback (e.g. Barbraud et al., 2008); sign (e.g. Sinclair, 1981) }\end{array}$} \\
\hline \multicolumn{3}{|c|}{ ( } \\
\hline Estimates & \multicolumn{2}{|l|}{ Burrow density; overall burrow estimate; occupancy; population size } \\
\hline Area & \multicolumn{2}{|l|}{ Area for extrapolation; proportion of the area surveyed } \\
\hline Dispersion & \multicolumn{2}{|c|}{ SD; SE; Cl of: burrow density $(d)$; burrow estimate $(b)$; occupancy $(o)$; population size $(N)$. } \\
\hline Reporting & \multicolumn{2}{|c|}{ Whether variance was reported for $d, b, o, N$} \\
\hline \multicolumn{2}{|c|}{ Explanatory variables } & Hypothesis \\
\hline Study/survey year & $\begin{array}{l}\text { Increasing number of studies generating population estimates = } \\
\text { lower uncertainty through collective knowledge gain }\end{array}$ & $\begin{array}{l}\text { Petrel status is deteriorating (Croxall et al., 2012), conservation } \\
\text { interventions are increasing (Brooke, Bonnaud, Dilley, Flint, } \\
\text { Holmes, Jones, Provost, Rocamora, Ryan, Surman, et al., 2018), } \\
\text { methods and technologies for assessing populations are } \\
\text { advancing (Rodríguez et al., 2019; Thompson, 2013), se we } \\
\text { predict uncertainty to decrease through time. }\end{array}$ \\
\hline Body-mass & Bigger bird = higher detectability = lower uncertainty & $\begin{array}{l}\text { Burrows of larger-bodied species are easier to detect, so we } \\
\text { predict uncertainty to be inversely proportional to body mass. }\end{array}$ \\
\hline $\begin{array}{l}\text { Species Red List } \\
\text { status }\end{array}$ & $\begin{array}{l}\text { More threatened = higher funding allocation and higher } \\
\text { consequences of uncertainty = lower uncertainty }\end{array}$ & $\begin{array}{l}\text { More threatened taxa received greater investment (Martín- } \\
\text { López et al., 2011; Possingham et al., 2002) carry higher potential } \\
\text { consequences of uncertain data, so we predict uncertainty to be } \\
\text { inversely correlated with threat status. }\end{array}$ \\
\hline Island size & $\begin{array}{l}\text { Bigger island = smaller subset of habitat sampled = higher } \\
\text { uncertainty because extrapolating to unsampled areas }\end{array}$ & $\begin{array}{l}\text { On smaller islands surveys can cover a greater proportion of the } \\
\text { island, whereas on large islands estimates will rely on }\end{array}$ \\
\hline
\end{tabular}


extrapolating to unsurveyed areas, so we predict uncertainty to be proportional to island size. 


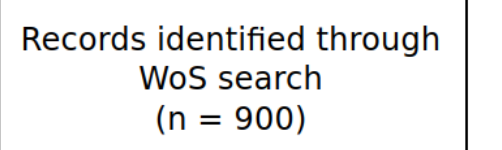

h
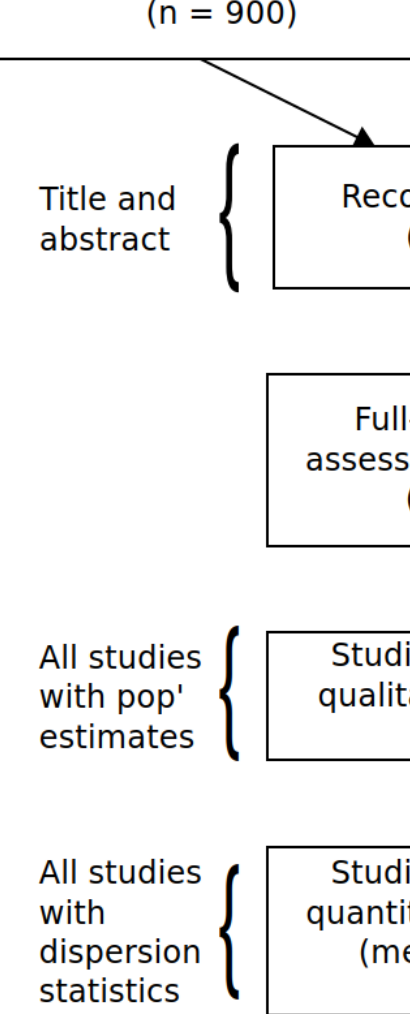

Additional records identified through other sources

$$
(\mathrm{n}=0)
$$

Figure 1: PRISMA flowchart adapted from Moher et al. (2009) documenting the search and screening steps in our review. 


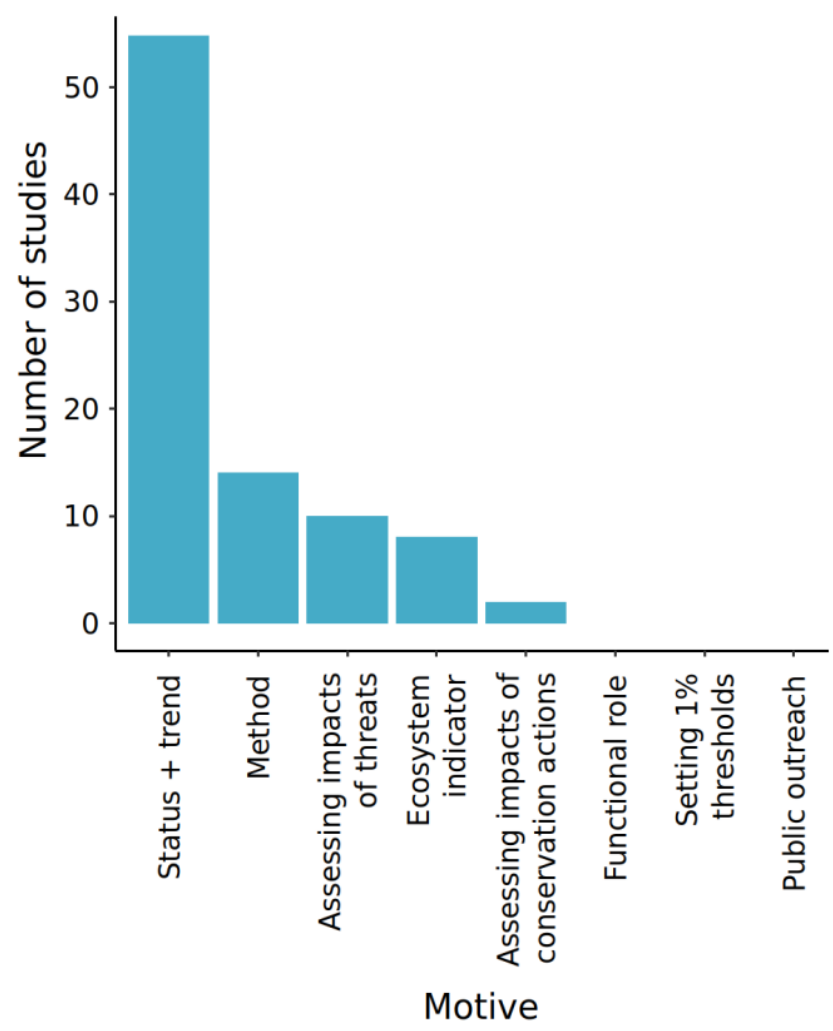

Figure 2: Motivations stated for estimating petrel population sizes from 68 studies. For detailed description of the motivations see Table 1. 'Method' was not predicted in Table 1 and reflects those studies for which the main motivation was to trial a method and test its utility for population estimation. 


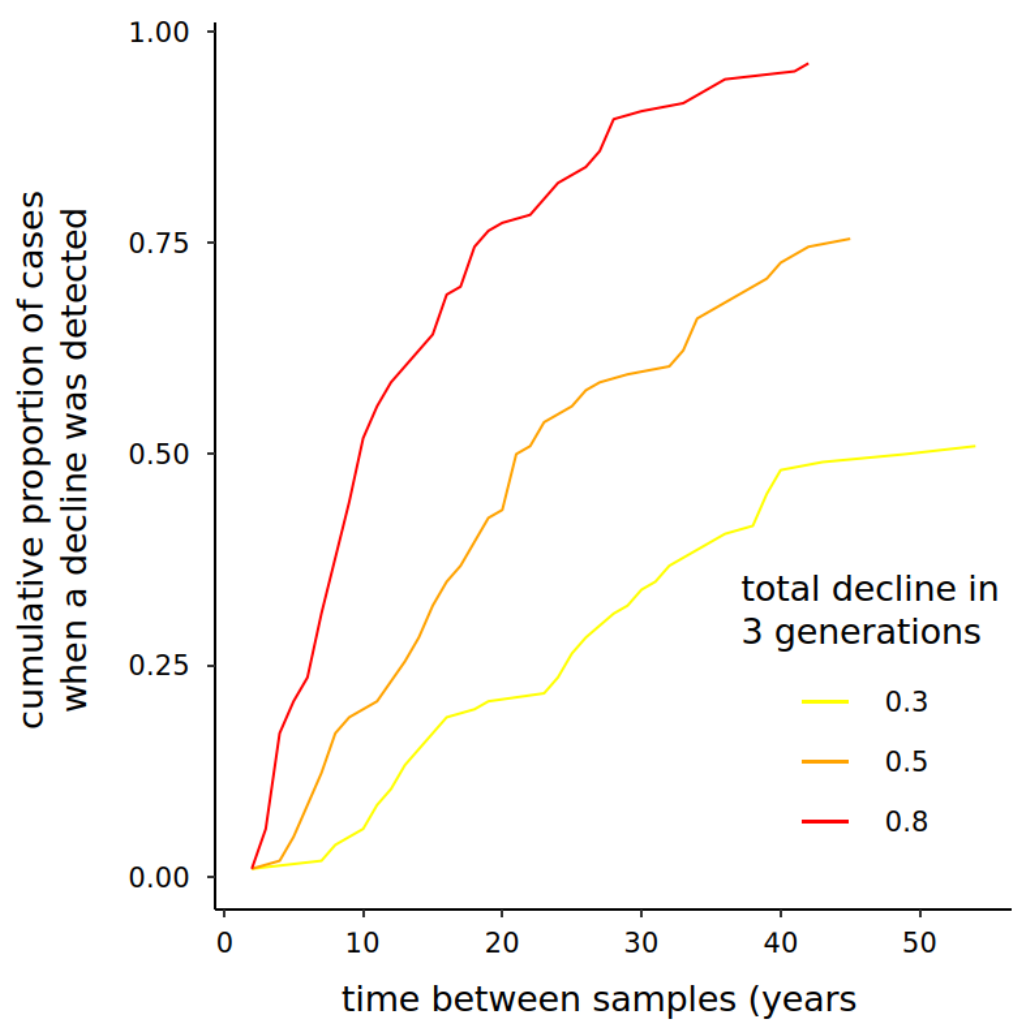

Figure 3: Based upon reported uncertainty, the proportion of studies able to detect significant population change after different lengths of time between repeat surveys given simulated rates of population declines equivalent to $30 \%, 50 \%$ and $80 \%$ over three generations (sensu IUCN 2020). 
bioRxiv preprint doi: https://doi.org/10.1101/2021.04.07.438872; this version posted April 9, 2021. The copyright holder for this preprint (which was not certified by peer review) is the author/funder, who has granted bioRxiv a license to display the preprint in perpetuity. It is made available under aCC-BY-NC-ND 4.0 International license.

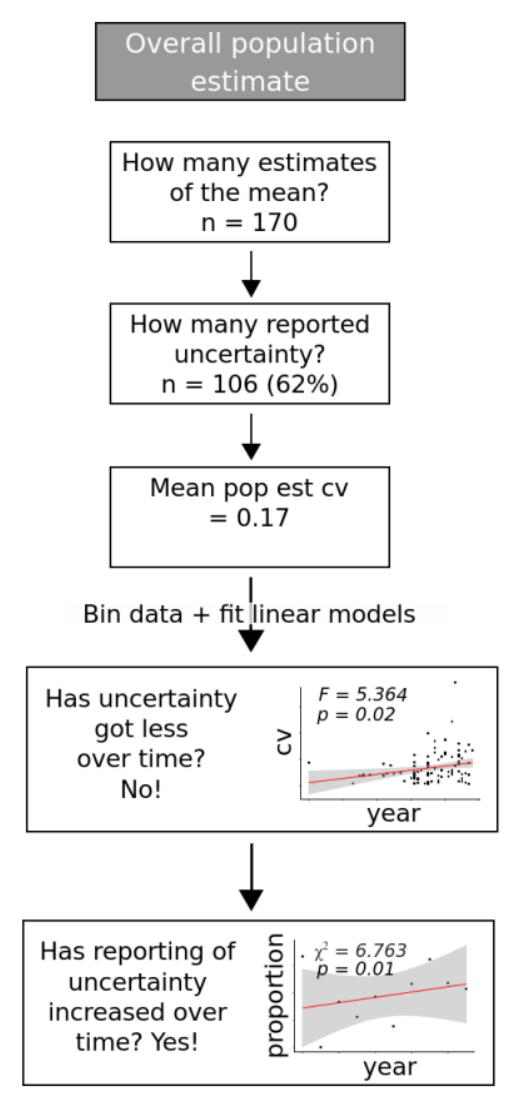

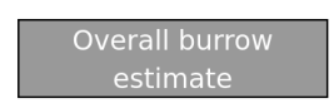
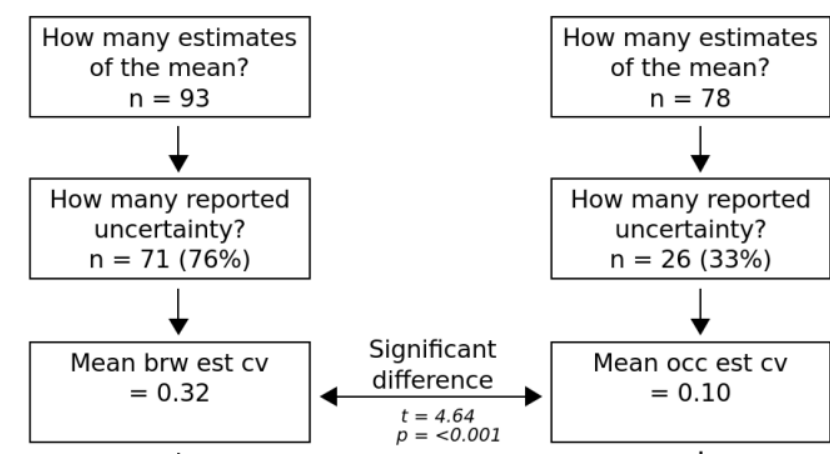

Has reporting of underlying parameters increased over time?
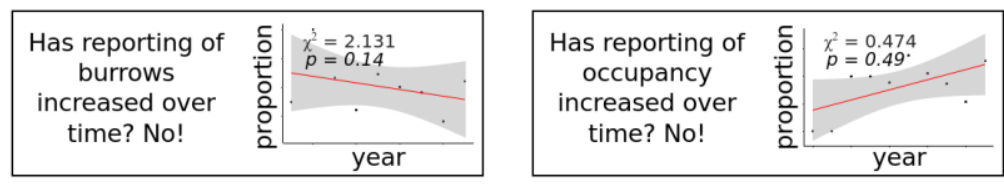

Has 'reporting of uncertainty increased over time?
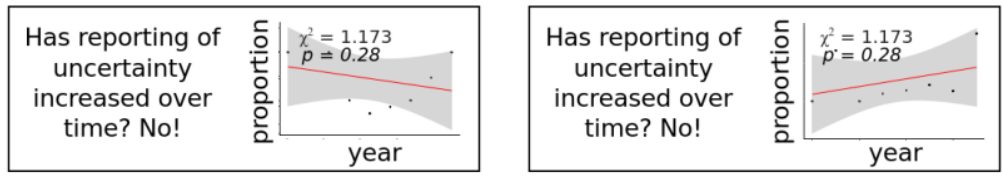

Figure 4: Reporting of petrel population estimates and the two key parameters that inform them,

burrow numbers and burrow occupancy. Trends in reporting and the magnitude of uncertainty for

all three parameters are included. 

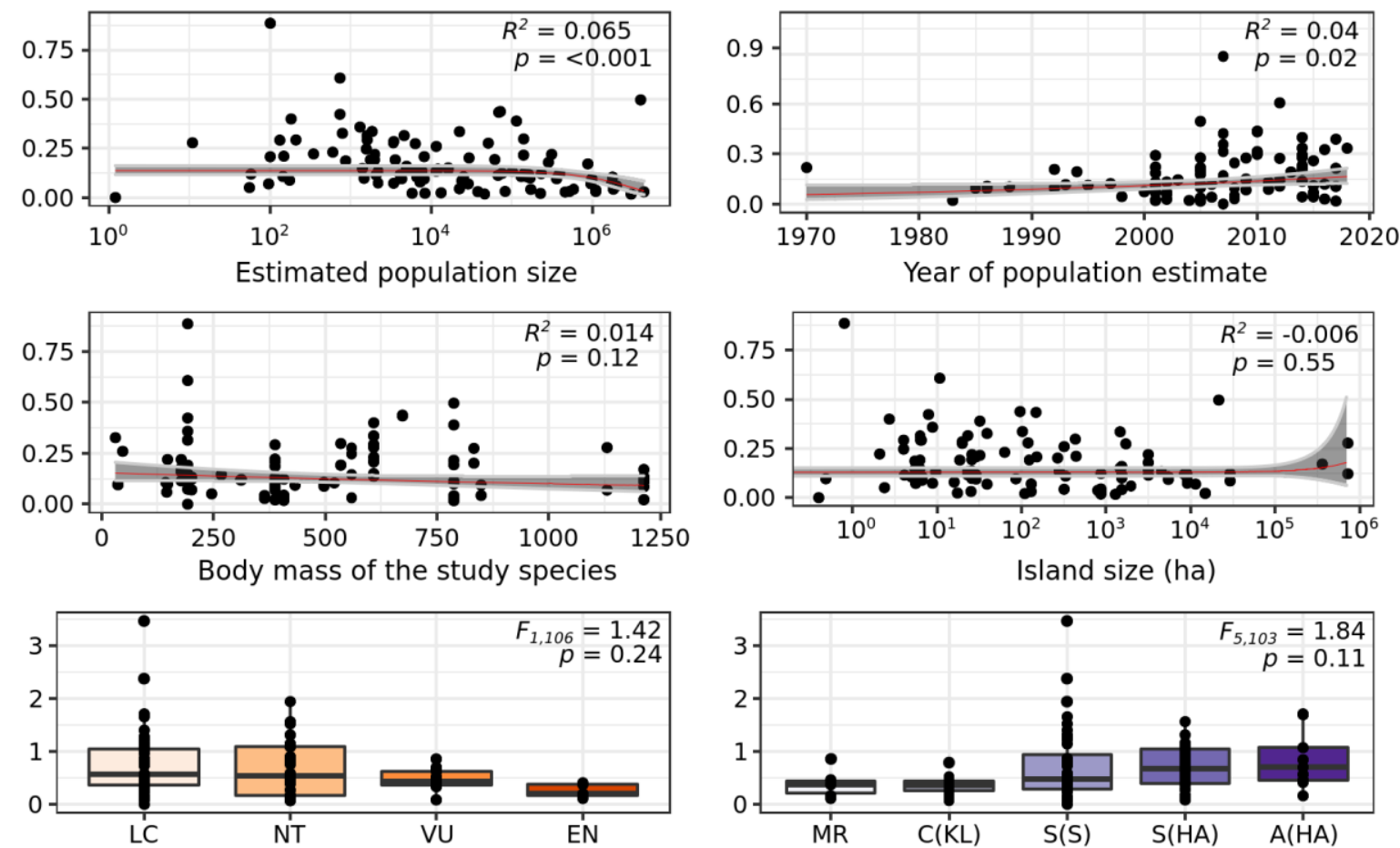

Red List status

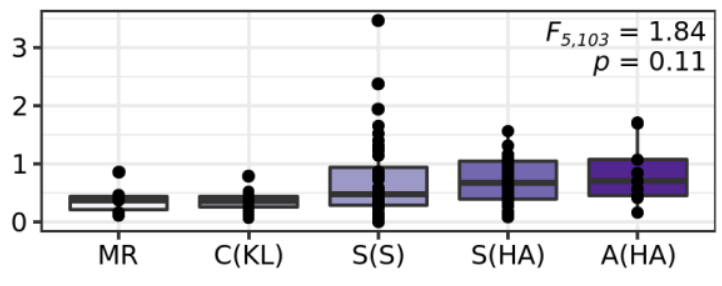

Survey method

Figure 5: Uncertainty in petrel population estimates in relation to explanatory variables. Red List categories are: Least Concern (LC), Near Threatened (NT), Vulnerable (VU) and Endangered (EN). Survey methods are derived from Rayner et al. (2007): mark recapture (MR), counts of known colonies (C[KL]), simple extrapolation (S[S]), simple habitat area models $(\mathrm{S}[\mathrm{HA}])$, advanced habitat area models (A[HA]), informed estimates (IE). 